\title{
志賀毒素産生性大腸菌の疫学
}

\section{Epidemiology of Shiga Toxin-Producing Escherichia coli}

\author{
西川禎一 ${ }^{\dagger}$ ・王＼cjkstart麗 麗
}

(大阪市立大学大学院生活科学研究科)

Yoshikazu Nishikawa and Lili Wang

(Graduate School of Human Life Science, Osaka City University,

Sugimoto, Sumiyosi-ku, Osaka $558-8585 ;{ }^{\dagger}$ Corresponding author)

\section{はじめに}

大腸菌 (Escherichia coli) は, 1885年にその名のとお り Escherichによって初めて報告された細菌である。恒 温動物の腸内に広く分布しており，ヒトにおいても出生 と同時に大腸菌が腸管内へと急速に広がり数日で粪便 $1 \mathrm{~g}$ 当たり $10^{11}$ にまで達する ${ }^{89)}$. 生後 5 日目ころにはビ フィズス菌が優勢となって大腸菌は減少するが, 糞便 $1 \mathrm{~g}$ 当たり $10^{8} \sim 10^{9}$ 程度のレベルで常在菌として定着す る ${ }^{89)}$. しかしながら, 大腸菌の一部には特殊な病原因子 によってヒトに下痢症を起こすものがあり，下痢原性大 腸菌（Diarrheagenic E. coli; 以後 DEC と略す）と呼ば れる。

DEC は, その病原機構に基づいて (1)腸管病原性大腸 菌 (Enteropathogenic E. coli; EPEC), (2) 腸管毒素原性 大腸菌 (Enterotoxigenic E. coli; ETEC), (3) 志賀毒素産 生性大腸菌 (Shiga toxin-producing E. coli; STEC), (4) 腸管侵入性大腸菌 (Enteroinvasive E. coli; EIEC), 以上 4 群に長らく大別されてきたが, その後（5）腸管凝集接 着性大腸菌 (Enteroaggregative E. coli; EAEC), (6) 分 散接着性大腸菌 (Diffusely adherent E. coli; DAEC) を 加えて6群に分けられている ${ }^{38)}$.

STECよりも腸管出血性大腸菌 (Enterohemorrhagic E. coli; EHEC) という呼称に馴染んでいる方が多いかも しれないが，STECの中でヒトに出血性大腸炎 (Hemorrhagic colitis; HC) を起こすことが確認されたものが EHECである，検査室で確認できるのは志賀毒素 (Shiga toxin; Stx) の産生やStx 遺伝子の保有までであり, HC の原因となった記録が明確な血清型菌であればEHEC と呼べるが, O157やO26あるいは O111 以外の血清型の 場合は判断しかねるときもあり, STECと呼ぶほうが間 違いはない. 腸粘膜への接着にかかわるインチミン遺伝

\section{連絡先}

寀558-8585 大阪市住吉区杉本3-3-138
子 (eae) と Stx 遺伝子を併せ持っているのがEHECとい う考え方もあるが51), eaeがなくても HCを起こした例 が報告されており ${ }^{8)}$, STEC分離の段階でEHECか否か 判定するのは難しい. 本稿ではSTECとして一括するこ とにする。

STECの血清型 O157 : H7 は 1996年に全国各地で集団 発生を起こし一般市民にも広く知られるところとなっ た. 病原性大腸菌（DECに対するマスコミ用語）と言 えばO157というイメージが広く定着していたが，2011 年は富山県を中心に焼肉チェーン店で STEC O111 によ る集団発生が起こり，また同時期にドイッを中心とする 欧州 14 力国でeae陰性のSTEC O104:H4による集団発 生も報じられて, O157以外の血清群のSTEC (NonO157 STEC) について関心が高まっている，そこで本稿 では, STECの血清型やその分布など疫学情報の紹介を 目的に文献情報の整理を試みた.

\section{1. 志賀毒素産生性大腸菌 (STEC)の歴史}

Konowalchukらは，大腸菌にはべロ細胞を傷害する 毒素（べロ毒素； verotoxin）を産生する株があること を発見し1977年に報告した ${ }^{45)}$ ，その後，出血性下痢症 例や腸炎罹患牛からべロ毒素産生性大腸菌 (Verotoxinproducing E. coli; VTEC) O26:H11 や 26 : H21の分離 が報告された ${ }^{83,85)}$.これらの報告は, VTECの病因学的 重要性を示しているが大きく注目されるには至らなかっ た.

1982 年に米国で起きた出血性大腸炎の集団発生事例 は, 「All blood, no stool」と称される特異な病像と致死 率の高さが注意をひいた ${ }^{16)}$. 原因菌として分離された EHEC O157 :H7がベロ毒素を産生したことから, 本毒 素も一気に注目を集めるところとなった，遡り調査に よって1973年には米国で, 1978年にはカナダと英国に も EHEC O157が分布していたことがわかったが28)，そ れ以前には存在しない新型菌と認識された。1983年に 
表1. STECの分類

I 血清型による2 群に分類

O157 重症度も発生頻度も高い

Non-O157

II Karmaliの血清型を用いた疫学的分類 ${ }^{41)}$

A $\quad$ O157:H7, O157:NM

B O26:H11, O103:H2, O111:NM, O121:H19, O145:NM

C O91: H21, O113: H21, H21のグループ

$\mathrm{D}$

E

III Scheutzの病原性による分類 ${ }^{48)}$

1 HUSや集団発生を起こす

2 ヒ下の下痢症原因となる

3 動物に関連しているがヒトに病原性がない

は英国 ${ }^{79)}, 1987$ 年にはベルギー ${ }^{67)}$ ，そして 1990 年には わが国でも O157による集団下痢症が発生し ${ }^{1)}$, EHEC という名はVTECという用語と渾然一体となって使わ れ広がった。

志賀赤痢菌1型が志賀毒素（Shiga toxin; Stx）を産生 することは1903年には報告されていた ${ }^{53)}$. O'Brienら は, 新型毒素とされてきたべロ毒素が実は既に報告され ていたStxファミリーに属するものであることを発見 ᄂ $58,59,77)$, VTEC感染症の特徵とされる溶血性尿毒症症 候群 (Hemolytic Uremic Syndrome; HUS) と志賀赤痢 菌1型による感染症との共通性も認識されるに至っ た ${ }^{42,59)}$. 今ではVTECよりも STECという呼称が優先 的に使用されつつある. 標的細胞の名前を付けて毒素名 とすること自体が異例であり Stx という用語こそが使用 されるべきと断言する毒素研究者もある.

\section{STECの分類}

\section{1）血清型による分類とその疫学}

O157の流行を通じてStx は毒素として一躍脚光を浴 びるところとなり，その産生菌である STEC は EHEC と 同義的に使われることが少なくない.しかしながら, EHEC はヒトの出血性大腸炎原因菌として確立された菌 群に対して使用されるべきであり，一方， STECという 呼称はStx 産生菌であれば使用できるがヒトへの病原性 を担保してはいない ${ }^{48)}$. ここにSTEC分類の難しさが生 じ, いくつかの考え方が提案されている41,48) (表1). いずれにせよ，STECから EHECを識別できる完全な指 標はなく, 広く捕捉するという意味でSTEC 全体を検出 報告の対象とするほうが検査現場では簡明である.

STECを鑑別するうえで血清型別や病原因子検索の必 要性は明らかであるが, 0157 と他の血清型菌を疫学的 に比較すると血便やHUSの発症はO157 感染者に顕著で あり ${ }^{30,48)}$ (表2), 発生頻度と重症度の高い 0157 だけを 調べていても STEC 感染症の多くを臨床的にはカバーで きるとの認識が根強い. 検査コストの問題もあって, 散 発症例の診断現場では O157 以外のSTECは看過されが ちである。しかし, 上述のように 157 以外のSTECの
重症度高く, 発生頻度も高い。

重症度高いが発生頻度やや低い

まれにHUSの散発例から検出されるが集団発生の頻度低い

下痢症から分離歴のある血清型

下㾥症から分離歴のない血清型

\begin{tabular}{|c|c|c|c|}
\hline & O157 & Non-O157 & 文献番号 \\
\hline 血便発症率 & $78 \%$ & $54 \%$ & 30 \\
\hline 入院率 & $34 \%$ & $8 \%$ & \\
\hline HUS発症率 & $7 \%$ & $0 \%$ & \\
\hline 入院率 & $42.0 \%$ & $12.0 \%$ & 48 \\
\hline HUS発症率 & $6.3 \%$ & $1.7 \%$ & \\
\hline 致死率 & $0.6 \%$ & $0.1 \%$ & \\
\hline
\end{tabular}

ほうが歴史的には古く，これらを無視できる状況にない ことは, 0104 や111など昨年の集団事例が示している とおりである。

国によって異なるがSTEC 感染症の 20～50\%は O 157 以外の血清型菌によるものであり ${ }^{37,51)}$, Meadらによる と, 米国の 1 年当たりの推定 STEC 感染患者数 11 万人の うち，Non-O157 STECによるものが 37,000 人に達する と推定している ${ }^{49)}$. 欧米ではHUSの 10〜30\%が O157 以 外の血清型によるという ${ }^{15)}$. 2009年に米国疾病管理予 防センターから出された勧告においても, O157用の選 択分離培地で下㢉患者便を培養し, O157様の細菌集落 を検索すると同時にStxのスクリーニングを実施するこ と, Stxが陽性であるにもかかわらず 0157 が検出され ない場合は検体か培養済みの培地あるいは $026 や 0111$ など主要なNon-O157 EHECの抗血清と反応した菌株を 公的研究機関に送付することが推奨されている ${ }^{27)}$. 検査 キットの開発により, 培養せずにStxのみの検出で判断 する傾向もあるが, これはかえって集団発生の発見など を遅延させるものとして, あくまでも培養との併用が勧 められている17, 18).

病原因子に関する分子遺伝学的な解析は急速に進んで いるが，上記のように臨床検査の第一線では血清型別が いまだ簡便かつ重要な判断材料であることも明らかであ る. そこで本項では O157 以外のSTECについて, Bettelheimの報告 ${ }^{7)}$ をベースに情報を追加, 血清型を整理 した（表3）. STECには500を超える血清型が報告され ているが29)，血便やHUSなどを起こすEHECとして認 識されているのは50ほどとされている ${ }^{51)}$. しかし，血 便の有無を問わずにHUSの原因として報告された 


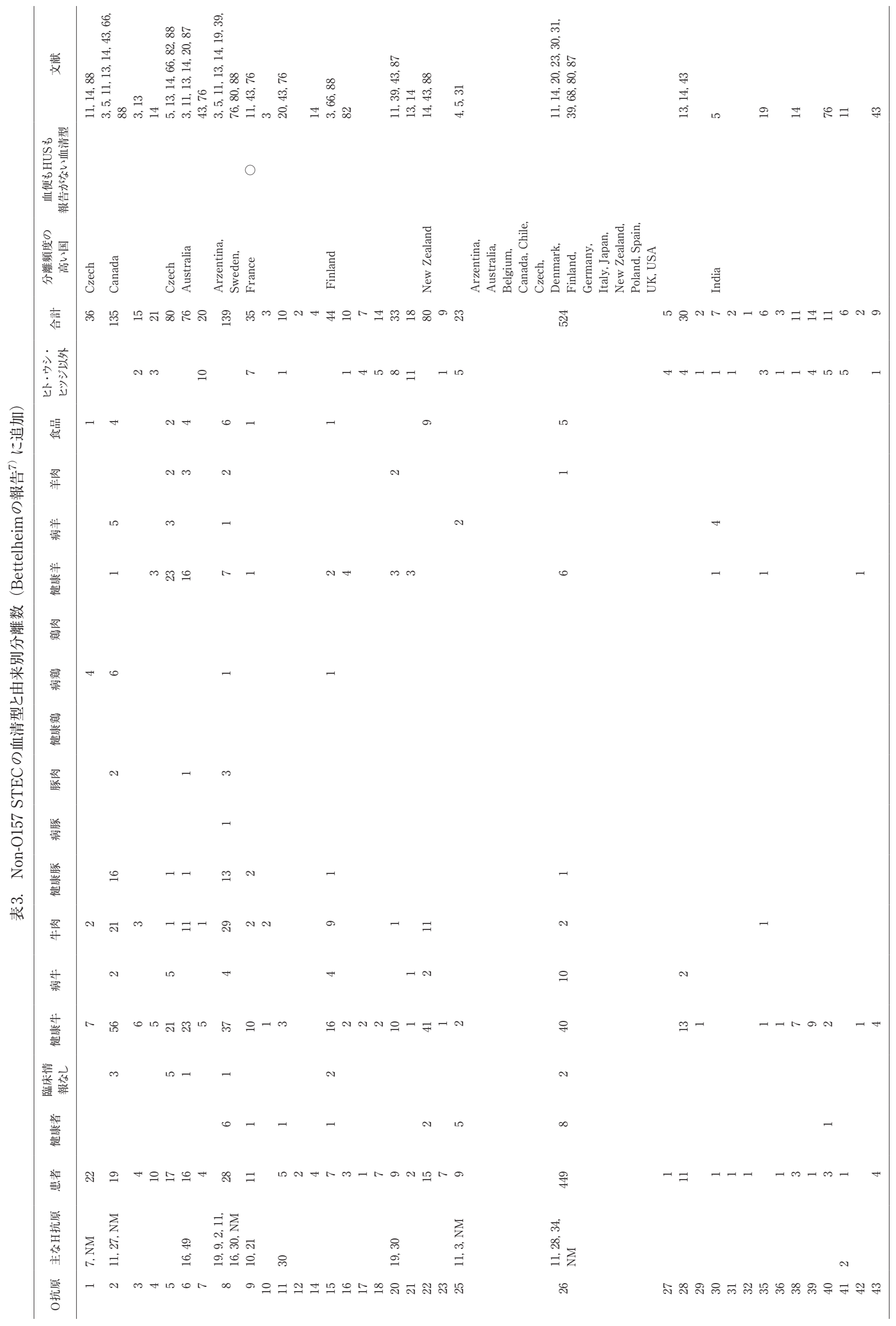




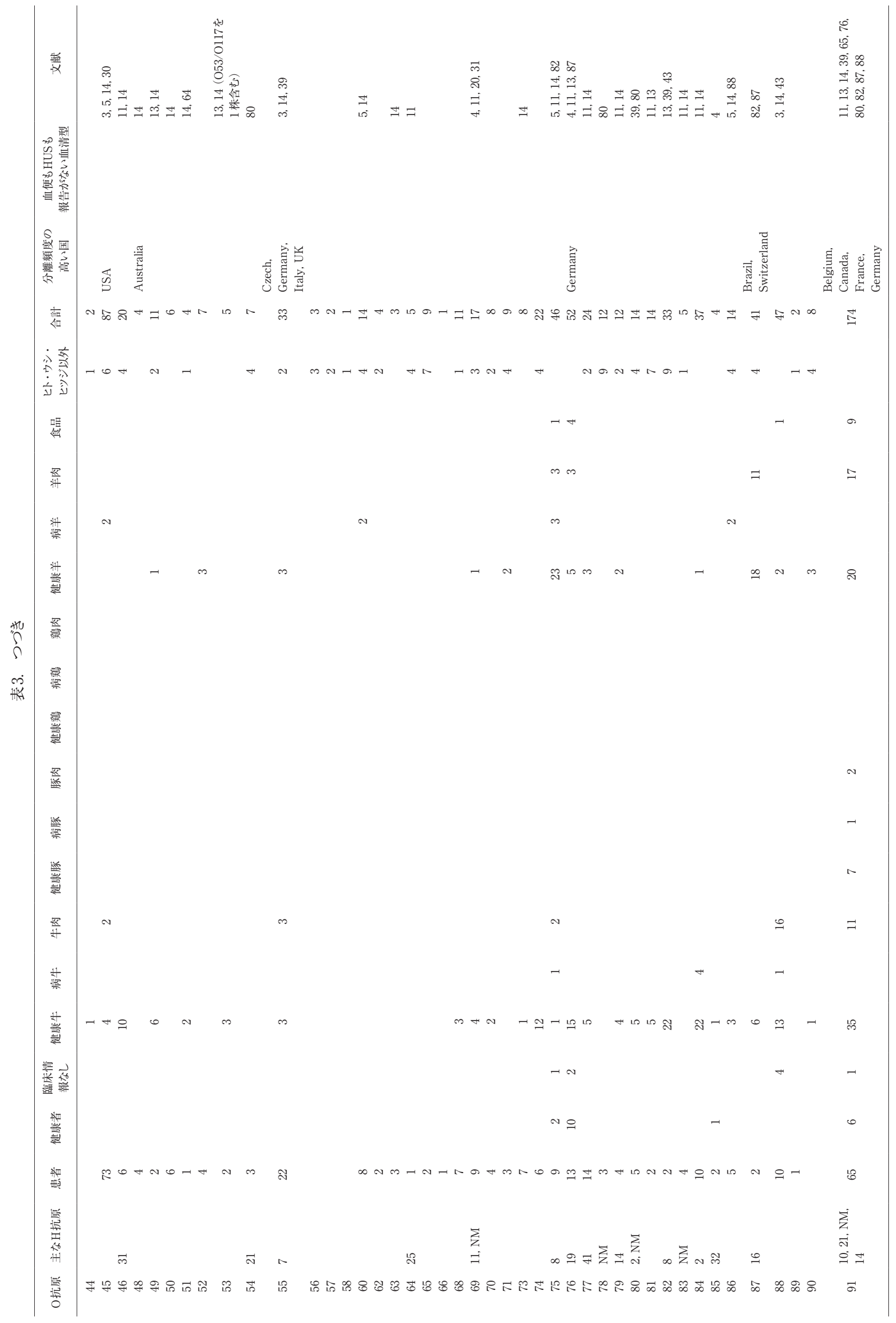




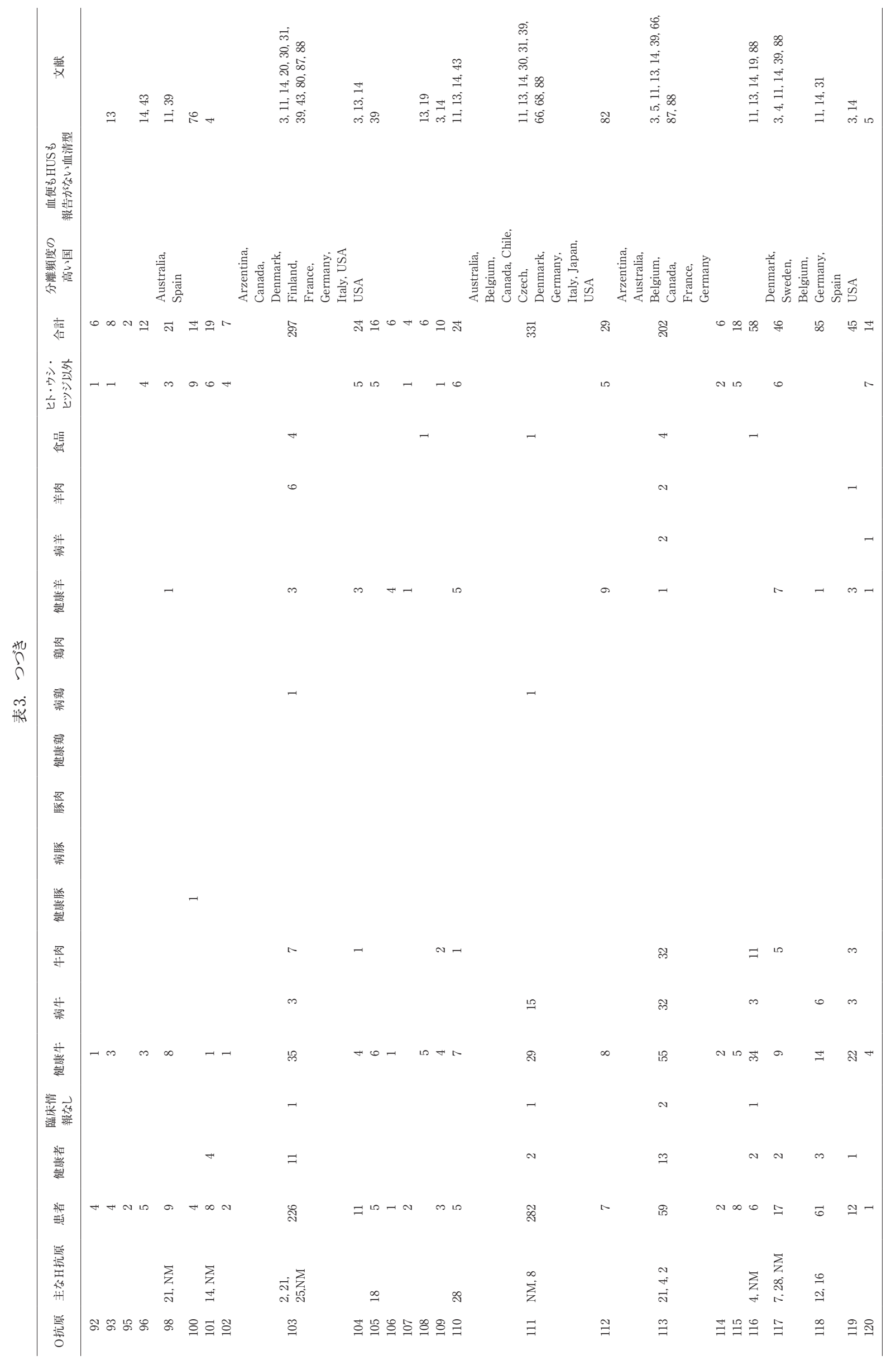




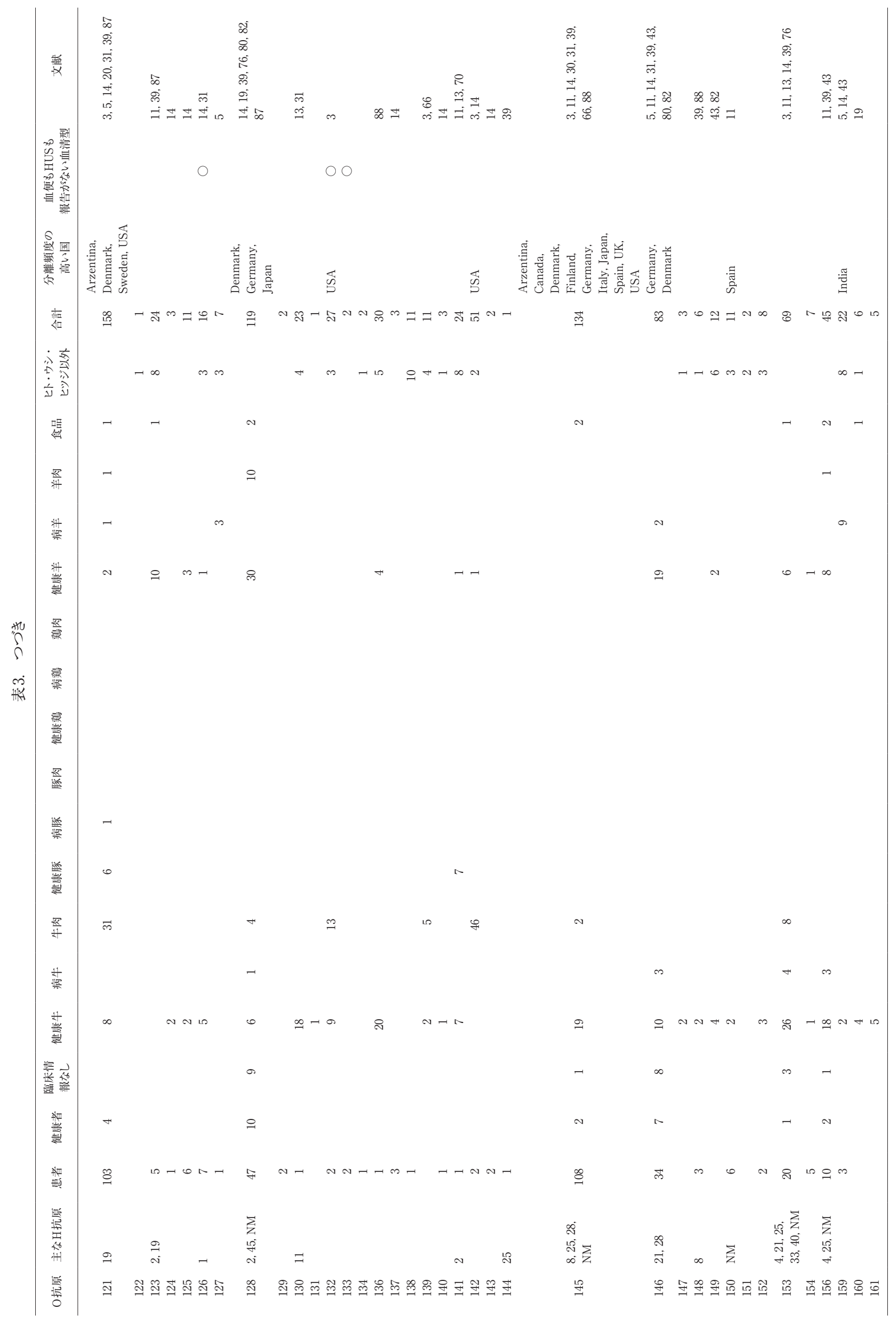




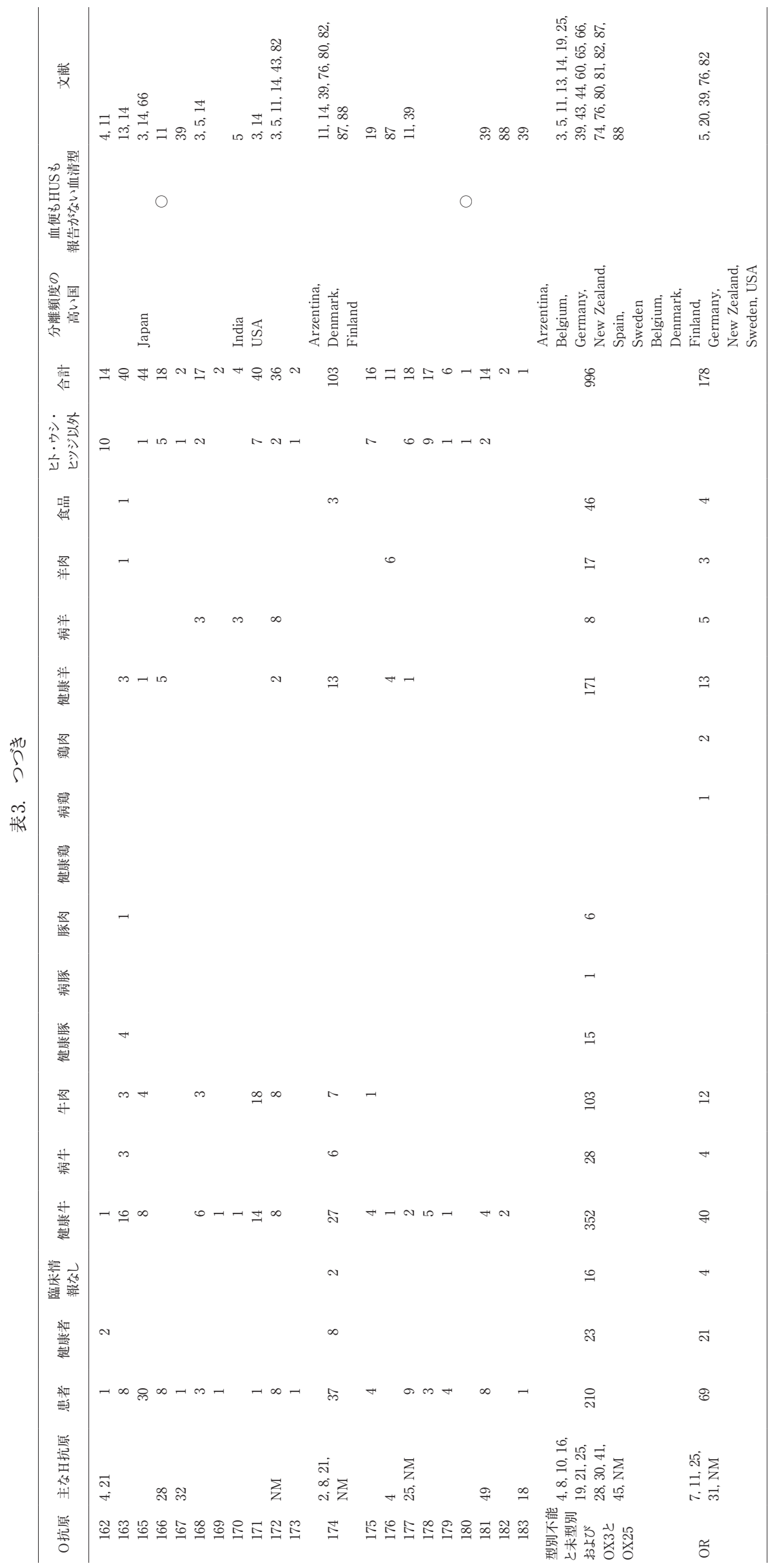




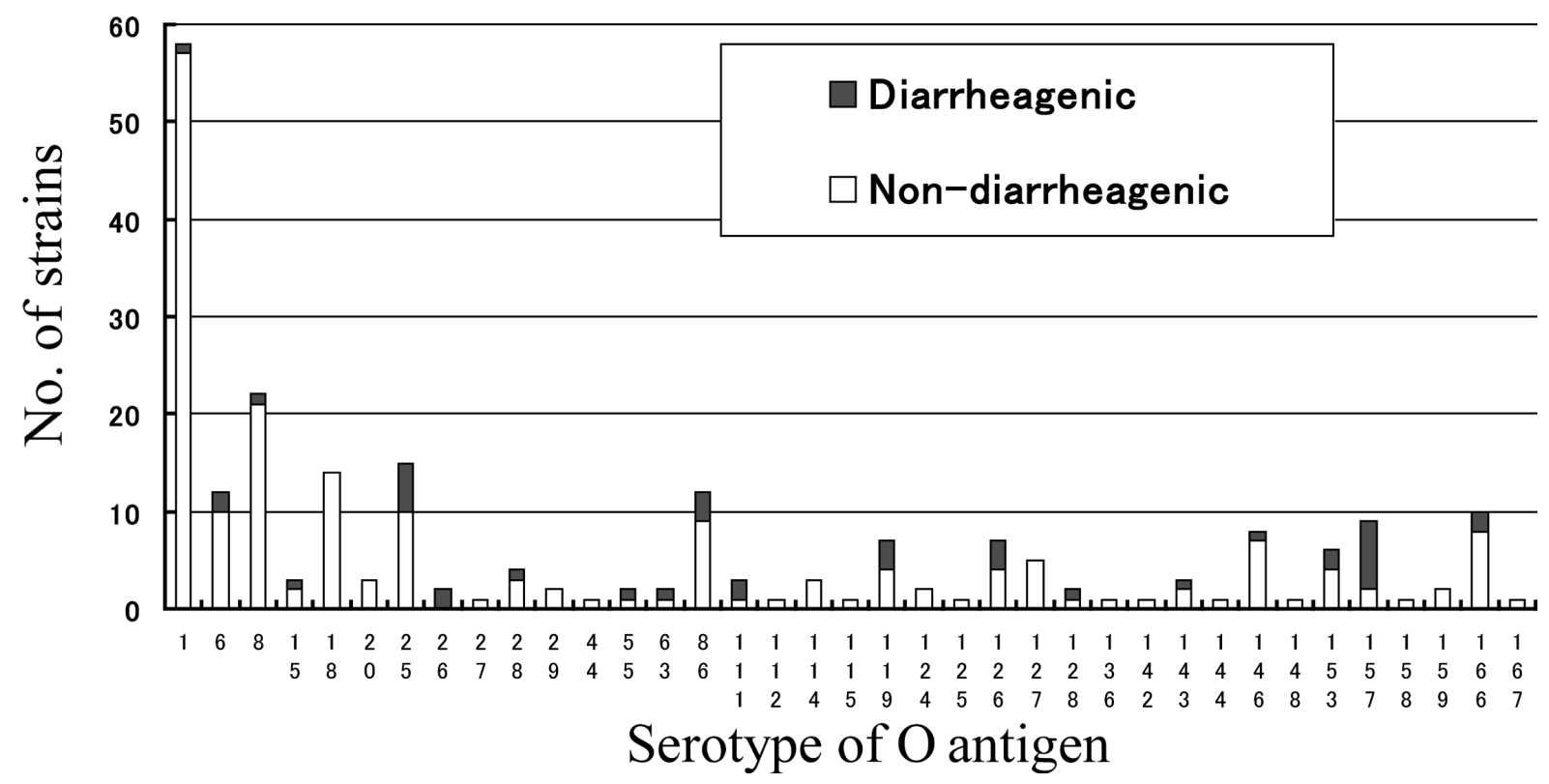

図1．散発下痢症例から分離された各 $\mathrm{O}$ 血清型大腸菌株に占める下痢原性大腸菌の割合 ${ }^{57)}$

STEC を拾い上げるとその血清型は 100 以上になる ${ }^{47)}$

O抗原と H抗原を合わせた血清型はSTECの鑑別に有 力であるが, H抗原は判定に時間を要するため現場では O抗原の決定のみとなることもある。 その際, O群ごと にDEC的中率は大きく異なる。図 1 は以前に大阪市で 実施したサーベイランスにおいて，各 O 血清群に分類 された株のうち実際に病原遺伝子を保有していた株の率 を示している ${ }^{57)}$. O26や 0157 など的中率の高い $\mathrm{O}$ 群も あるが，01のように極端に的中率の低い群もある。し たがって，EHECが疑われる状況下で O26, O91, O103, O111, O113, O118, O121, O128, O145 などの O 群の菌が 検出された場合は，疑似扱いで予備的に報告することも 臨床現場では考えうる. しかし, 食品や家畜など患者以 外の検体から分離された場合はStxの確認が必須とな る.TSIなどの鑑別培地に分離培養された菌苔の残りが あれば，ポリミキシン Bで破壊した上清を適当な Stx 検 出キットと反応させることで PCRなどを利用しなくて も容易に検出できるはずである ${ }^{6,7,27)}$. ただし, 菌を分 離したとき既にStx 遺伝子が脱落してしまっていること もある ${ }^{2,10)}$. 血便や HUSなどEHEC感染が疑われる状 況下で分離された大腸菌株で，血清型がEHECによく 見られる型と一致した場合はStx 確認できなくても原 因菌の可能性が高く, 血清型は重要な判断基準となる. 2011 年の富山県でのユッケを原因食品としたO111によ る事例でも同様の事象が報告されている.

\section{2）毒素型による分類}

Stxは標的細胞に付着するためにBサブユニット（分 子量 $7.7 \mathrm{kDa}$ の B フラグメントが5つリング状に集合し た 5 量体）と細胞傷害性を発揮する $\mathrm{A}$ サブユニット（分 子量 $32 \mathrm{kDa}$ ）一つから構成される A-B型のホロ毒素で ある. STECが産生するのは, 志賀赤痢菌のStxに近似
したStx $1^{35)}$ と，抗原性や遺伝子の相同性が大きく異な るStx2 $2^{34,73)}$ に大別され (表4)，それぞれがまた複数の

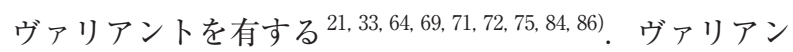
トについては用語が重複していると考えられ，またアミ ノ酸配列に違いがあっても毒素活性や抗原性がどの程度 変化しているのか, その生物学的意義も含めて完全には 説明されていないが, 疫学的に臨床症状とStxの型との 関連が示唆されている.

これら種々のStx は培養細胞に対する毒性も大きく異 なり, HeLa細胞に対する毒性はStx1・Stx2>Stx2c・ $\mathrm{Stx} 2 \mathrm{~d}>\mathrm{Stx} 2 \mathrm{e} \cdot \mathrm{Stx} 2 \mathrm{f}$ の順になるのに対して, MDBK細 胞では順序が逆転するという ${ }^{47)}$. その理由としては, Stx の細胞毒性試験に用いられる標準的な株化細胞であ るVero細胞がStxの受容体となる Gb3およびGb4の両 方を細胞表面に発現しているのに対して, HeLa細胞は Gb3のみを, MDBK 細胞はGb4のみを保有するためと

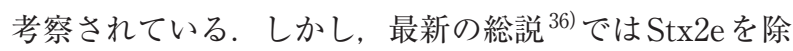
く全てのStxにおいて Gb3が受容体とされており，標的 細胞に対する各Stx の結合力の違いは Gb3 を構成する脂 肪酸の種類や長さと不飽和度に応じて Bサブユニットの 親和性が異なるためであり, STEC感染患者において重 症度に違いが出るのも各人が有する Gb3の性状の違い によるようだ ${ }^{54,62)}$.

上記の観察および考察の妥当性については毒素の専門 家に結論を委ねたいが，いずれにせよStxの種類によっ て毒性に違いがあることについては異論の余地はない. 生体内での毛細血管内皮細胞に対するStx2の毒性は Stx1の1,000倍高いとの報告もあり ${ }^{46)}$ ， ヒトにおける Stx2の毒性の強さは広く知られている ${ }^{61)}$. 0157 だけで はなく, Non-O157 STECでも Stx2遺伝子保有株がHUS を起こし重症化する傾向が強く ${ }^{12,22)}$, その型別は予後に 
表4．志賀毒素の型別 ${ }^{36,46}$

\begin{tabular}{|c|c|c|c|c|c|c|}
\hline \multirow{2}{*}{ 志賀毒素 } & \multirow{2}{*}{ 同 義 語 } & \multicolumn{3}{|c|}{ Homology (\%) } & \multirow{2}{*}{ 備 } & \multirow{2}{*}{ 文献番号 } \\
\hline & & A subunit & B subunit & Receptors & & \\
\hline 赤㾥菌 Stx* & & 100 & 100 & Gb3 & \multirow{7}{*}{$\begin{array}{l}\text { Stx2vhaとStx2vhbを含む } \\
\text { Stx2d-O111, Stx2d-OX3a, } \\
\text { Stx2d-Ountも含む } \\
\text { ブタ浮腫病に特異的 } \\
\text { ハトから分離された株のStx }\end{array}$} & \\
\hline Stx1 & SLTI, VT1 & 97 & 98 & Gb3 & & 35 \\
\hline Stxlc & SLTIc, VT1c & 97 & 98 & Gb3 & & 86 \\
\hline Stx2 & SLTII, VT2 & 53 & 64 & Gb3 & & 34,73 \\
\hline Stx $2 c^{* *}$ & SLTIIc, VT2c & 53 & 61 & Gb3 & & $21,33,69,72$ \\
\hline Stx2d & SLTIId, VT2d & 54 & 61 & Gb3 & & 64,75 \\
\hline Stx $2 e^{*}$ & SLTIIe, VT2e & 53 & 61 & $\mathrm{~Gb} 3$ and $\mathrm{Gb} 4$ & & 26,84 \\
\hline Stx $2 f^{*}$ & SLTIIf, VT2f & 54 & 60 & Gb3 & $\begin{array}{l}\text { でヒトに対する病原性は未 } \\
\text { 確定 }\end{array}$ & 71 \\
\hline
\end{tabular}

*ファージにコードされていない

** Stx2vOX393, Stx2vOX392もStx2cにに近い

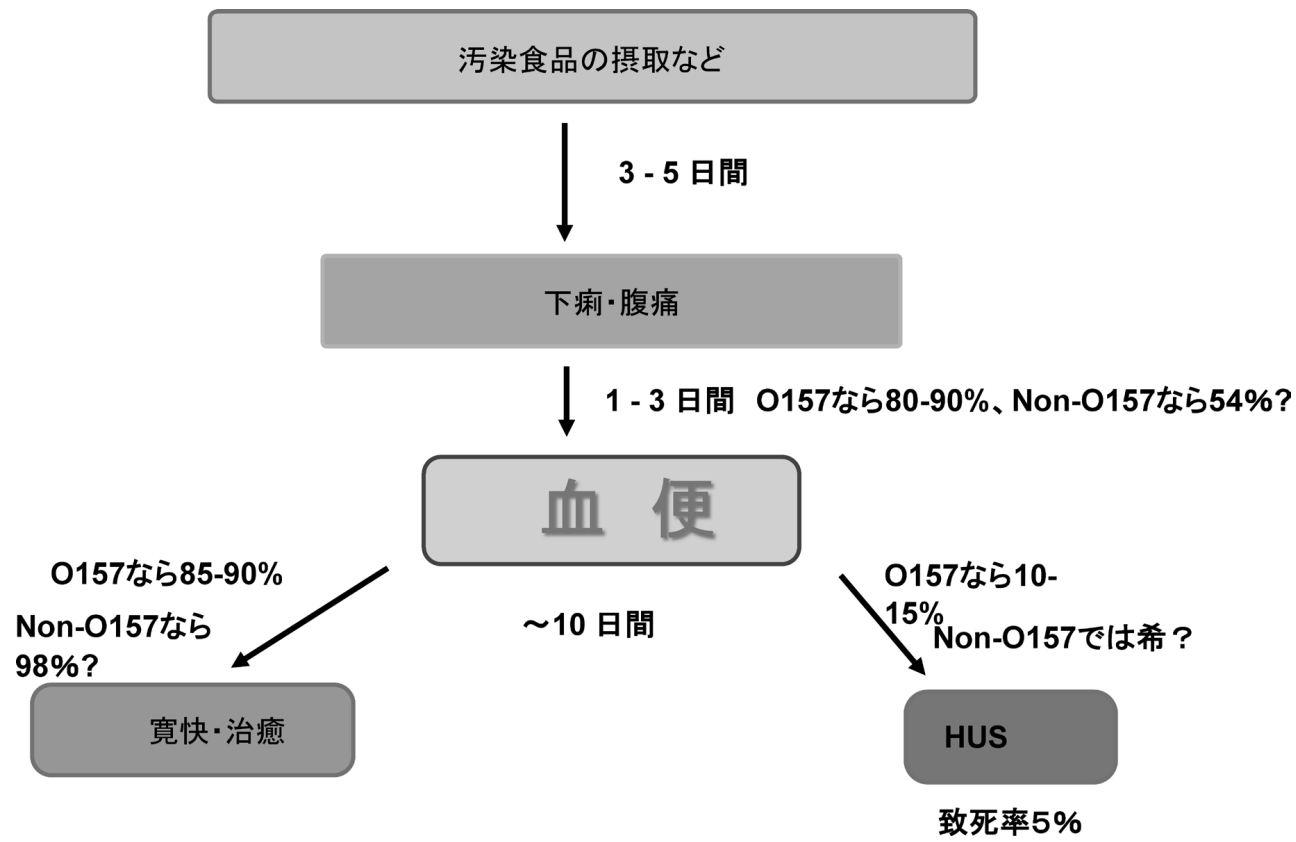

図 2. STEC 感染症の経過

も大きく影響する。筆者らは, O157のStx2保有菌株は Stx1 P Stx2vha（現在の分類ではStx2c）のみを保有す る株に比べて血便を発症させる率が高いことを見いだ し, 変異型Stx2遺伝子のみを保有する 0157 菌株では逆 受け身ラテックス凝集反応で調べた毒素産生量も低いこ とを報告した ${ }^{56)}$. しかしながら，これが変異型Stx2の 産生量の低さを示したものか，あるいは検出に用いられ た抗 Stx2抗体とStx2vha との反応性が低いために見か け上低くなったのか定かでなく, 変異型 Stx2 産生菌感 染者における血便発症率の低さが毒素の質的な違いによ るのか, 産生量が少ないせいなのか, あるいは両方なの か不明である. Stx2cについてはHUSを起こすこともあ るが, Stx2dおよびStx2e保有菌は重篤な症状につなが る可能性は低く，Stx2e は専らブ夕に病原性のある毒素

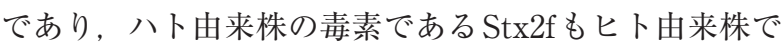

の報告はまれである ${ }^{9,21,26,71,84)}$ 。このように, Stxの型 別は単なる疫学マーカーではなく臨床上の予後にも重要 な意味を持つ。

\section{3) 付着因子}

EHECやEPECの付着にかかわる因子としてインチミ ンとこれをコードする $e a e$ 遺伝子はよく知られている. 前述のようにStx2の病原性は他のStxよりも強いとされ ているが, eae保有菌株の場合にHUS発症のリスクはよ り高くなるとの報告があり ${ }^{14,48)}$, 分離株のStx型ととも に付着因子も予後に影響する。eaeについては 14 種類以 上の変異型があり, インチミンに対する受容体の役割を 果たすTir蛋白質の遺伝子と Tir 宿主細胞に打ち込む 3 型分泌装置の構成成分の遺伝子である espについても 3 種類以上の変異型が知られている ${ }^{47)}$. これら変異型と臨 床症状や宿主特異性の関連はいまだ明らかではない. 
eaeを保有しなくても代替付着因子として saaを保有 する $0113: \mathrm{H} 21$ のような株や，本年欧州で大規模な集団 感染を起こしたO 104 : H4のようにEAECの付着因子遺 伝子を有する菌も感染した患者に重篤な症状を起こした ことから, eaeを保有しない株も強い病原性を有する可 能性がある ${ }^{52,55)}$. 1998年にも Morabito らがaggR 保有 する EHEC O111:H2 によるHUSの集団発生を報告して おり ${ }^{50)}$, 今回の $\mathrm{O} 104: \mathrm{H} 4$ を例外的な菌とは言えない. 1994年に米国モンタナ州で起きた集団下㾥症の原因菌 O104: H21 もeaeを保有していなかったが, この菌が

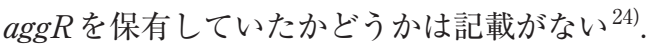

\section{STEC 感染症の経過}

O157感染事例の研究によるデータが多いが, 総 説 ${ }^{32,40,48,63)}$ から共通項を拾い出してみた。潜伏期間は 1〜9日間だが多くは 3〜 5日で下媊を起こす（図2）。そ の後，治癒寛快へと向かう患者も少なくないが，重症化 する場合は下痢発症から 1 ～3 日間で腹痛の増悪ととも に血性下痢へと移行する．Non-O157 よりも0157 のほう が出血性大腸炎への移行率は高く，この状態は10日間 に及ぶこともある。 0157 感染の場合は下痢発症から 5〜13日で10〜15\%がHUSの症状を示すようになり， HUS患者の致死率は約 5\%に達するのに対して, NonO157感染でのHUS発症は0 1.7\%にとどまる，逆に HUSにならずに治癒する率は Non-O157感染群のほうが 高い。しかしながら，Non-O157をO157 よりも病原性の 低い群と単純化するのが容易でないことは，昨年のわが 国での 0111 や欧州の 0104 の事例からも容易に推察さ れる. 毒素の型（特にStx2）や付着因子（eaeや $\operatorname{aggR}$ ） の有無を考慮して過去のデー夕を再検討すべきであろ う.

O157 感染の場合，下痢あるいは出血性大腸炎患者 （中央值 3.6 歳）に扔ける排菌期間は $2 \sim 62$ 日間で中央值 は13日間だが，HUSを発症した患者では5〜124日間で 中央值21日間に及ぶ。 ヒトからヒトへの感染も多く, 集団発生に拄ける患者の $20 \%$ は二次感染である.HUS は子どもに特に多く，英国では1997年から 2001年まで にHUSに罹患した 350 症例の $65 \%$ が5歳以下であった. HUSを発症した場合はその半数が腎透析を必要とする. HUS 罹患率は国によって異なるが，アルゼンチンの 5 歳 以下の子どもの罹患率は 10 万人当たり $12 て ゙ ，$ 他国の 10 倍近い状況である ${ }^{32,78)}$.

\section{4. ま とめ}

STEC 感染症では, 抗生物質が本菌による毒素産生や 放出を促す可能性があるので使用しないほうが良いとす る意見が欧米を中心に少なくない。つまり臨床細菌の同 定結果が治療方針に大きな影響を与えることになり，本 菌の診断には迅速性が求められる。分子遺伝学的な検査 手法や免疫学的な検出法が開発され, 臨床細菌の検査は
まさに日進月歩である。ベッドサイドでStxのスクリー ニングが優先されるのも無理もない，しかしながら，米 国CDCの勧告にもあるように，集団発生を探知する意 味でも菌分離とその型別は欠かせないものである ${ }^{17,18) .}$

集団発生時などは，探査している原因菌を識別する最 も簡便な手法としてスライド凝集試験はいまだ捨てがた い. そこで今回は, O157 以外のSTECの現状を把握し ていただきスライド凝集試験の結果を判断する際の参考 になればと考え，文献情報の整理を試みた。あくまでも 英文原著論文に限っての情報収集であり, 多くの分離情 報が集積されていると思われる各国の衛生統計デー夕 ベースには着手できていない，どこまで実態を反映でき たのか測りかねるが，患者の症状から STEC感染症が疑 われるような場合に，分離菌の O抗原と表 3 の中の検出 頻度を参考にしていただければ, リスク判定に役立つか もしれないと期待している。

\section{文献}

1) Akashi, S., Joh, K., Tsuji, A., Ito, H., Hoshi, H., Hayakawa, T., Ihara, J., Abe, T., Hatori, M., Mori, T., et al.: A severe outbreak of haemorrhagic colitis and haemolytic uraemic syndrome associated with Escherichia coli O157 : H7 in Japan. Eur. J. Pediatr., 153, 650-655 (1994).

2) Albert, M. J., Rotimi, V. O., Dhar, R., Silpikurian, S., Pacsa, A. S., Molla, A. M. and Szucs, G.: Diarrhoeagenic Escherichia coli are not a significant cause of diarrhoea in hospitalised children in Kuwait. BMC Microbiology, 9, 62 (2009).

3) Arthur, T. M., Barkocy-Gallagher, G. A., Rivera-Betancourt, M. and Koohmaraie, M.: Prevalence and characterization of non-O157 Shiga toxin-producing Escherichia coli on carcasses in commercial beef cattle processing plants. Appl. Environ. Microbiol., 68, 48474852 (2002).

4) Aslani, M. M. and Bouzari, S.: Characterization of virulence genes of non-O157 Shiga toxin-producing Escherichia coli isolates from two provinces of Iran. Jpn. J. Infect. Dis., 62, 16-19 (2009).

5) Bandyopadhyay, S., Mahanti, A., Samanta, I., Dutta, T. K., Ghosh, M. K., Bera, A. K. and Bhattacharya, D.: Virulence repertoire of Shiga toxin-producing Escherichia coli (STEC) and enterotoxigenic Escherichia coli (ETEC) from diarrhoeic lambs of Arunachal Pradesh, India. Trop. Anim. Hlth. Prod., 43, 705-710 (2011).

6) Bettelheim, K. A.: Development of a rapid method for the detection of verocytotoxin-producing Escherichia coli (VTEC). Lett. Appl. Microbiol., 33, 31-35 (2001).

7) Bettelheim, K. A.: The non-O157 shiga-toxigenic (verocytotoxigenic) Escherichia coli; under-rated pathogens. Crit. Rev. Microbiol., 33, 67-87 (2007).

8) Beutin, L., Krause, G., Zimmermann, S., Kaulfuss, S. and Gleier, K.: Characterization of Shiga toxin-producing Escherichia coli strains isolated from human patients in Germany over a 3-year period. J. Clin. Microbiol., 42, 1099-1108 (2004). 
9) Beutin, L., Kruger, U., Krause, G., Miko, A., Martin, A. and Strauch, E.: Evaluation of major types of Shiga toxin 2E-producing Escherichia coli bacteria present in food, pigs, and the environment as potential pathogens for humans. Appl. Environ. Microbiol., 74, 4806-4816 (2008).

10) Bielaszewska, M., Middendorf, B., Kock, R., Friedrich, A. W., Fruth, A., Karch, H., Schmidt, M. A. and Mellmann, A.: Shiga toxin-negative attaching and effacing Escherichia coli: Distinct clinical associations with bacterial phylogeny and virulence traits and inferred inhost pathogen evolution. Clin. Infect. Dis., 47, 208-217 (2008).

11) Blanco, J. E., Blanco, M., Alonso, M. P., Mora, A., Dahbi, G., Coira, M. A. and Blanco, J.: Serotypes, virulence genes, and intimin types of Shiga toxin (verotoxin)-producing Escherichia coli isolates from human patients: prevalence in Lugo, Spain, from 1992 through 1999. J. Clin. Microbiol., 42, 311-319 (2004).

12) Boerlin, P., McEwen, S. A., Boerlin-Petzold, F., Wilson, J. B., Johnson, R. P. and Gyles, C. L.: Associations between virulence factors of Shiga toxin-producing Escherichia coli and disease in humans. J. Clin. Microbiol., 37, 497503 (1999).

13) Brett, K. N., Hornitzky, M. A., Bettelheim, K. A., Walker, M. J. and Djordjevic, S. P.: Bovine non-O157 Shiga toxin 2-containing Escherichia coli isolates commonly possess stx2-EDL933 and/or stx2vhb subtypes. J. Clin. Microbiol., 41, 2716-2722 (2003).

14) Brooks, J. T., Sowers, E. G., Wells, J. G., Greene, K. D., Griffin, P. M., Hoekstra, R. M. and Strockbine, N. A.: Non-O157 Shiga toxin-producing Escherichia coli infections in the United States, 1983-2002. J. Infect. Dis., 192, 1422-1429 (2005).

15) Caprioli, A., Tozzi, A. E., Rizzoni, G. and Karch, H.: NonO157 Shiga toxin-producing Escherichia coli infections in Europe. Emerg. Infect. Dis., 3, 578-579 (1997).

16) Centers for Disease, C.: Isolation of E. coli O157:H7 from sporadic cases of hemorrhagic colitis-United States. MMWR Morb. Mortal. Wkly. Rep., 31, 580, 585 (1982).

17) Centers for Disease, C. and Prevention: Importance of culture confirmation of shiga toxin-producing Escherichia coli infection as illustrated by outbreaks of gastroenteritis-New York and North Carolina, 2005. MMWR Morb. Mortal. Wkly. Rep., 55, 1042-1045 (2006).

18) Centers for Disease, C. and Prevention: Laboratory-confirmed non-O157 Shiga toxin-producing Escherichia coli-Connecticut, 2000-2005. MMWR Morb. Mortal. Wkly. Rep., 56, 29-31 (2007).

19) Cobbold, R. N., Davis, M. A., Rice, D. H., Szymanski, M., Tarr, P. I., Besser, T. E. and Hancock, D. D.: Associations between bovine, human, and raw milk, and beef isolates of non-O157 Shiga toxigenic Escherichia coli within a restricted geographic area of the United States. J. Food. Prot., 71, 1023-1027 (2008).

20) Couturier, M. R., Lee, B., Zelyas, N. and Chui, L.: Shigatoxigenic Escherichia coli detection in stool samples screened for viral gastroenteritis in Alberta, Canada. J. Clin. Microbiol., 49, 574-578 (2011).

21) Eklund, M., Leino, K. and Siitonen, A.: Clinical Escherichia coli strains carrying stx genes: stx variants and stx-positive virulence profiles. J. Clin. Microbiol., 40, 4585-4593 (2002).

22) Erickson, M. C. and Doyle, M. P.: Food as a vehicle for transmission of Shiga toxin-producing Escherichia coli. J. Food Prot., 70, 2426-2449 (2007).

23) Ethelberg, S., Smith, B., Torpdahl, M., Lisby, M., Boel, J., Jensen, T., Nielsen, E. M. and Molbak, K.: Outbreak of non-O157 Shiga toxin-producing Escherichia coli infection from consumption of beef sausage. Clin. Infect. Dis., 48, e78-e81 (2009).

24) Feng, P., Weagant, S. D. and Monday, S. R.: Genetic analysis for virulence factors in Escherichia coli O104: H21 that was implicated in an outbreak of hemorrhagic colitis. J. Clin. Microbiol., 39, 24-28 (2001).

25) Fremaux, B., Delignette-Muller, M. L., Prigent-Combaret, C., Gleizal, A. and Vernozy-Rozand, C.: Growth and survival of non-O157:H7 Shiga-toxin-producing Escherichia coli in cow manure. J. Appl. Microbiol., 102, 89-99 (2007).

26) Friedrich, A. W., Bielaszewska, M., Zhang, W. L., Pulz, M., Kuczius, T., Ammon, A. and Karch, H.: Escherichia coli harboring Shiga toxin 2 gene variants: frequency and association with clinical symptoms. J. Infect. Dis., 185, 74-84 (2002).

27) Gould, L. H., Bopp, C., Strockbine, N., Atkinson, R., Baselski, V., Body, B., Carey, R., Crandall, C., Hurd, S., Kaplan, R., Neill, M., Shea, S., Somsel, P., Tobin-D’Angelo, M., Griffin, P. M., Gerner-Smidt, P., Centers for Disease, C. and Prevention: Recommendations for diagnosis of Shiga toxin-producing Escherichia coli infections by clinical laboratories. MMWR Recomm. Rep., 58, 1-14 (2009).

28) Griffin, P. M. and Tauxe, R. V.: The epidemiology of infections caused by Escherichia coli $\mathrm{O} 157$ : H7, other enterohemorrhagic E. coli, and the associated hemolytic uremic syndrome. Epidemiol Rev., 13, 60-98 (1991).

29) Gyles, C. L.: Shiga toxin-producing Escherichia coli: an overview. J. Anim. Sci., 85, E45-E62 (2007).

30) Hedican, E. B., Medus, C., Besser, J. M., Juni, B. A., Koziol, B., Taylor, C. and Smith, K. E.: Characteristics of $\mathrm{O} 157$ versus non-O157 Shiga toxin-producing Escherichia coli infections in Minnesota, 2000-2006. Clin. Infect. Dis., 49, 358-364 (2009).

31) Hermos, C. R., Janineh, M., Han, L. L. and McAdam, A. J.: Shiga toxin-producing Escherichia coli in children: diagnosis and clinical manifestations of $\mathrm{O} 157: \mathrm{H} 7$ and non-O157 : H7 infection. J. Clin. Microbiol., 49, 955-959 (2011).

32) Hunt, J. M.: Shiga toxin-producing Escherichia coli (STEC). Clin. Lab. Med., 30, 21-45 (2010).

33) Ito, H., Terai, A., Kurazono, H., Takeda, Y. and Nishibuchi, M.: Cloning and nucleotide sequencing of Vero toxin 2 variant genes from Escherichia coli $\mathrm{O} 91$ : H21 isolated from a patient with the hemolytic uremic 
syndrome. Microb. Pathog., 8, 47-60 (1990).

34) Jackson, M. P., Neill, R. J., Obrien, A. D., Holmes, R. K. and Newland, J. W.: Nucleotide sequence analysis and comparison of the structural genes for Shiga-like toxin I and Shiga-like toxin II encoded by bacteriophages from Escherichia coli 933. FEMS Microbiol. Lett., 44, 109-114 (1987).

35) Jackson, M. P., Newland, J. W., Holmes, R. K. and Obrien, A. D.: Nucleotide-sequence analysis of the structural genes for Shiga-like toxin I encoded by bacteriophage 933J from Escherichia coli. Microb. Pathog., 2, 147-153 (1987).

36) Johannes, L. and Romer, W.: Shiga toxins-from cell biology to biomedical applications. Nat. Rev. Microbiol., 8, 105-116 (2010).

37) Johnson, K. E., Thorpe, C. M. and Sears, C. L.: The emerging clinical importance of non-O157 Shiga toxinproducing Escherichia coli. Clin. Infect. Dis., 43, 15871595 (2006).

38) Kaper, J. B., Nataro, J. P. and Mobley, H. L.: Pathogenic Escherichia coli. Nat. Rev. Microbiol., 2, 123-140 (2004).

39) Kappeli, U., Hachler, H., Giezendanner, N., Beutin, L. and Stephan, R.: Human infections with non-O157 Shiga toxin-producing Escherichia coli, Switzerland, 20002009. Emerg. Infect. Dis., 17, 180-185 (2011).

40) Karmali, M. A., Gannon, V. and Sargeant, J. M.: Verocytotoxin-producing Escherichia coli (VTEC). Vet. Microbiol., 140, 360-370 (2010).

41) Karmali, M. A., Mascarenhas, M., Shen, S., Ziebell, K., Johnson, S., Reid-Smith, R., Isaac-Renton, J., Clark, C., Rahn, K. and Kaper, J. B.: Association of genomic O island 122 of Escherichia coli EDL 933 with verocytotoxin-producing Escherichia coli seropathotypes that are linked to epidemic and/or serious disease. J. Clin. Microbiol., 41, 4930-4940 (2003).

42) Karmali, M. A., Steele, B. T., Petric, M. and Lim, C.: Sporadic cases of haemolytic-uraemic syndrome associated with faecal cytotoxin and cytotoxin-producing Escherichia coli in stools. Lancet, 1, 619-620 (1983).

43) Khan, A., Yamasaki, S., Sato, T., Ramamurthy, T., Pal, A., Datta, S., Chowdhury, N. R., Das, S. C., Sikdar, A., Tsukamoto, T., Bhattacharya, S. K., Takeda, Y. and Nair, G. B.: Prevalence and genetic profiling of virulence determinants of non-O157 Shiga toxin-producing Escherichia coli isolated from cattle, beef, and humans, Calcutta, India. Emerg. Infect. Dis., 8, 54-62 (2002).

44) Koitabashi, T., Cui, S., Kamruzzaman, M. and Nishibuchi, M.: Isolation and characterization of the Shiga toxin gene (stx)-bearing Escherichia coli $\mathrm{O} 157$ and nonO157 from retail meats in Shandong Province, China, and characterization of the O157-derived stx2 phages. J. Food Prot., 71, 706-713 (2008).

45) Konowalchuk, J., Speirs, J. I. and Stavric, S.: Vero response to a cytotoxin of Escherichia coli. Infect. Immun., 18, 775-779 (1977).

46) Louise, C. B. and Obrig, T. G.: Specific interaction of Escherichia coli O157:H7-derived Shiga-like toxin II with human renal endothelial cells. J. Infect. Dis., 172,
1397-1401 (1995).

47) Mainil, J. G. and Daube, G.: Verotoxigenic Escherichia coli from animals, humans and foods: who's who? J. Appl. Microbiol., 98, 1332-1344 (2005).

48) Mathusa, E. C., Chen, Y., Enache, E. and Hontz, L.: NonO157 Shiga toxin-producing Escherichia coli in foods. J. Food. Prot., 73, 1721-1736 (2010).

49) Mead, P. S., Slutsker, L., Dietz, V., McCaig, L. F., Bresee, J. S., Shapiro, C., Griffin, P. M. and Tauxe, R. V.: Food-related illness and death in the United States. Emerg. Infect. Dis., 5, 607-625 (1999).

50) Morabito, S., Karch, H., Mariani-Kurkdjian, P., Schmidt, H., Minelli, F., Bingen, E. and Caprioli, A.: Enteroaggregative, Shiga toxin-producing Escherichia coli O111:H2 associated with an outbreak of hemolyticuremic syndrome. J. Clin. Microbiol., 36, 840-842 (1998).

51) Nataro, J. P. and Kaper, J. B.: Diarrheagenic Escherichia coli. Clin. Microbiol. Rev., 11, 142-201 (1998).

52) Neill, M. A.: Overview of verotoxigenic Escherichia coli. J. Food Prot., 60, 1444-1446 (1997).

53) Neisser, M. and Shiga, K.: Ueber freie Receptoren von Typhus- und Dysenteriebazillen und uber das Dysenterietoxin. Dtsch. Med. Wochenschr., 29, 61-62 (1903).

54) Newburg, D. S., Chaturvedi, P., Lopez, E. L., Devoto, S., Fayad, A. and Cleary, T. G.: Susceptibility to hemolyticuremic syndrome relates to erythrocyte glycosphingolipid patterns. J. Infect. Dis., 168, 476-479 (1993).

55) Newton, H. J., Sloan, J., Bulach, D. M., Seemann, T., Allison, C. C., Tauschek, M., Robins-Browne, R. M., Paton, J. C., Whittam, T. S., Paton, A. W. and Hartland, E. L.: Shiga toxin-producing Escherichia coli strains negative for locus of enterocyte effacement. Emerg. Infect. Dis, 15, 372-380 (2009).

56) Nishikawa, Y., Zhou, Z., Hase, A., Ogasawara, J., Cheasty, T. and Haruki, K.: Relationship of genetic type of Shiga toxin to manifestation of bloody diarrhea due to enterohemorrhagic Escherichia coli serogroup O157 isolates in Osaka City, Japan. J. Clin. Microbiol., 38, 2440-2442 (2000).

57) Nishikawa, Y., Zhou, Z., Hase, A., Ogasawara, J., Kitase, T., Abe, N., Nakamura, H., Wada, T., Ishii, E., Haruki, K. and team, S.: Diarrheagenic Escherichia coli isolated from stools of sporadic cases of diarrheal illness in Osaka City, Japan between 1997 and 2000: prevalence of enteroaggregative E. coli heat-stable enterotoxin 1 gene-possessing E. coli. Jpn. J. Infect. Dis., 55, 183-190 (2002).

58) O’Brien, A. D. and Holmes, R. K.: Shiga and Shiga-like toxins. Microbiol. Rev., 51, 206-220 (1987).

59) O’Brien, A. D., LaVeck, G. D., Thompson, M. R. and Formal, S. B.: Production of Shigella dysenteriae type 1-like cytotoxin by Escherichia coli. J. Infect. Dis., 146, 763-769 (1982).

60) Oporto, B., Esteban, J. I., Aduriz, G., Juste, R. A. and Hurtado, A.: Escherichia coli $\mathrm{O} 157$ : $\mathrm{H} 7$ and non-O157 Shiga toxin-producing E. coli in healthy cattle, sheep and swine herds in Northern Spain. Zoonoses Pub. Hlth., 55, 73-81 (2008). 
61) Ostroff, S. M., Tarr, P. I., Neill, M. A., Lewis, J. H., Hargrett-Bean, N. and Kobayashi, J. M.: Toxin genotypes and plasmid profiles as determinants of systemic sequelae in Escherichia coli $\mathrm{O} 157$ : $\mathrm{H} 7$ infections. J. Infect. Dis., 160, 994-998 (1989).

62) Pellizzari, A., Pang, H. and Lingwood, C. A.: Binding of verocytotoxin 1 to its receptor is influenced by differences in receptor fatty acid content. Biochemistry, 31, 1363-1370 (1992).

63) Pennington, H.: Escherichia coli O157. Lancet, 376, 1428-1435 (2010).

64) Pierard, D., Muyldermans, G., Moriau, L., Stevens, D. and Lauwers, S.: Identification of new verocytotoxin type 2 variant B-subunit genes in human and animal Escherichia coli isolates. J. Clin. Microbiol., 36, 33173322 (1998).

65) Pradel, N., Boukhors, K., Bertin, Y., Forestier, C., Martin, C. and Livrelli, V.: Heterogeneity of Shiga toxin-producing Escherichia coli strains isolated from hemolyticuremic syndrome patients, cattle, and food samples in central France. Appl. Environ. Microbiol., 67, 2460-2468 (2001).

66) Renter, D. G., Bohaychuk, V., Van Donkersgoed, J. and King, R.: Presence of non-O157 Shiga toxin-producing Escherichia coli in feces from feedlot cattle in Alberta and absence on corresponding beef carcasses. Can. J. Vet. Res., 71, 230-235 (2007).

67) Robaeys, G., Surmont, I., Lemmens, P., Coremans, G., Vantrappen, G. and Vandepitte, J.: Haemorrhagic colitis and verotoxin-producing Escherichia coli $\mathrm{O} 157$ in Belgium. Lancet, 1, 1495-1496 (1987).

68) Rogerie, F., Marecat, A., Gambade, S., Dupond, F., Beaubois, P. and Lange, M.: Characterization of Shiga toxin producing $E$. coli and $O 157$ serotype $E$. coli isolated in France from healthy domestic cattle. Int. J. Food Microbiol., 63, 217-223 (2001).

69) Russmann, H., Schmidt, H., Caprioli, A. and Karch, H.: Highly conserved B-subunit genes of Shiga-like toxin II variants found in Escherichia coli 0157 strains. FEMS Microbiol. Lett., 118, 335-340 (1994).

70) Schierack, P., Steinruck, H., Kleta, S. and Vahjen, W.: Virulence factor gene profiles of Escherichia coli isolates from clinically healthy pigs. Appl. Environ. Microbiol., 72, 6680-6686 (2006).

71) Schmidt, H., Scheef, J., Morabito, S., Caprioli, A., Wieler, L. H. and Karch, H.: A new Shiga toxin 2 variant (Stx2f) from Escherichia coli isolated from pigeons. Appl. Environ. Microbiol., 66, 1205-1208 (2000).

72) Schmitt, C. K., McKee, M. L. and O’Brien, A. D.: Two copies of Shiga-like toxin II-related genes common in enterohemorrhagic Escherichia coli strains are responsible for the antigenic heterogeneity of the $\mathrm{O} 157: \mathrm{H}^{-}$ strain E32511. Infect. Immun., 59, 1065-1073 (1991).

73) Scotland, S. M., Smith, H. R. and Rowe, B.: Two distinct toxins active on vero cells from Escherichia coli $\mathrm{O} 157$. Lancet, 2, 885-886 (1985).

74) Sobieszczanska, B., Gryko, R., Kuzko, K. and Dworniczek, E.: Prevalence of non-O157 Escherichia coli strains among shiga-like toxin-producing (SLTEC) isolates in the region of Lower Silesia, Poland. Scand. J. Infect. Dis., 36, 219-221 (2004).

75) Stephan, R. and Hoelzle, L. E.: Characterization of shiga toxin type 2 variant B-subunit in Escherichia coli strains from asymptomatic human carriers by PCRRFLP. Lett. Appl. Microbiol., 31, 139-142 (2000).

76) Stephan, R. and Schumacher, S.: Resistance patterns of non-O157 Shiga toxin-producing Escherichia coli (STEC) strains isolated from animals, food and asymptomatic human carriers in Switzerland. Lett. Appl. Microbiol., 32, 114-117 (2001).

77) Strockbine, N. A., Marques, L. R., Newland, J. W., Smith, H. W., Holmes, R. K. and O’Brien, A. D.: Two toxin-converting phages from Escherichia coli O157 : H7 strain 933 encode antigenically distinct toxins with similar biologic activities. Infect. Immun., 53, 135-140 (1986).

78) Tarr, P. I., Gordon, C. A. and Chandler, W. L.: Shiga-toxin-producing Escherichia coli and haemolytic uraemic syndrome. Lancet, 365, 1073-1086 (2005).

79) Taylor, C. M., White, R. H., Winterborn, M. H. and Rowe, B.: Haemolytic-uraemic syndrome: clinical experience of an outbreak in the West Midlands. Br. Med. J. (Clin. Res. Ed.), 292, 1513-1516 (1986).

80) van Duynhoven, Y. T., Friesema, I. H., Schuurman, T., Roovers, A., van Zwet, A. A., Sabbe, L. J., van der Zwaluw, W. K., Notermans, D. W., Mulder, B., van Hannen, E. J., Heilmann, F. G., Buiting, A., Jansen, R. and Kooistra-Smid, A. M.: Prevalence, characterisation and clinical profiles of Shiga toxin-producing Escherichia coli in the Netherlands. Clin. Microbiol. Infect., 14, 437-445 (2008).

81) Varela-Hernandez, J. J., Cabrera-Diaz, E., Cardona-Lopez, M. A., Ibarra-Velazquez, L. M., Rangel-Villalobos, H., Castillo, A., Torres-Vitela, M. R. and Ramirez-Alvarez, A.: Isolation and characterization of Shiga toxinproducing Escherichia coli $\mathrm{O} 157$ :H7 and non-O157 from beef carcasses at a slaughter plant in Mexico. Int. J. Food Microbiol., 113, 237-241 (2007).

82) Vettorato, M. P., de Castro, A. F. P., Cergole-Novella, M. C., Camargo, F. L. L., Irino, K. and Guth, B. E. C.: Shiga toxin-producing Escherichia coli and atypical enteropathogenic Escherichia coli strains isolated from healthy sheep of different populations in Sao Paulo, Brazil. Lett. Appl. Microbiol., 49, 53-59 (2009).

83) Wade, W. G., Thom, B. T. and Evans, N.: Cytotoxic enteropathogenic Escherichia coli. Lancet, 2, 1235-1236 (1979).

84) Weinstein, D. L., Jackson, M. P., Samuel, J. E., Holmes, R. K. and O'Brien, A. D.: Cloning and sequencing of a Shiga-like toxin type II variant from Escherichia coli strain responsible for edema disease of swine. J. Bacteriol., 170, 4223-4230 (1988).

85) Wilson, M. W. and Bettelheim, K. A.: Cytotoxic Escherichia coli serotypes. Lancet, 1, 201 (1980).

86) Zhang, W. L., Bielaszewska, M., Kuczius, T. and Karch, H.: Identification, characterization, and distribution of a 
Shiga toxin 1 gene variant (stx(1c)) in Escherichia coli strains isolated from humans. J. Clin. Microbiol., 40, 1441-1446 (2002).

87) Zweifel, C., Blanco, J. E., Blanco, M., Blanco, J. and Stephan, R.: Serotypes and virulence genes of ovine non-O157 Shiga toxin-producing Escherichia coli in Switzerland. Int. J. Food Microbiol., 95, 19-27 (2004).
88) Zweifel, C., Schumacher, S., Blanco, M., Blanco, J. E., Tasara, T., Blanco, J. and Stephan, R.: Phenotypic and genotypic characteristics of non-O157 Shiga toxin-producing Escherichia coli (STEC) from Swiss cattle. Vet. Microbiol., 105, 37-45 (2005).

89) 光岡知足: 腸内菌叢の形成, 推移, 分布. 腸内細菌学. 光岡知足編, p. 87-107, 朝倉書店, 東京 (1990). 